\title{
Kepemilikan Amanah Dalam Islam
}

\author{
M. Zia Ulhaq* \\ * Mahasiswa Pascasarjana, Fakultas Ilmu Agama Islam \\ Universitas Islam Indonesia, Yogyakarta \\ Email: Ziaulhaq8816@gmail.com
}

\begin{abstract}
Abstrak: Kepemilikan adalah suatu ikatan seseorang dengan hak miliknya yang disahkan syariah. Kepemilikan berarti pula hak khusus yang didapatkan si pemilik sehingga mempunyai hal menggunakan sejauh tidak melakukan pelanggaran pada garis-garis syariah. Penelitian ini fokus mengkaji mengenai bagaimana kepemilikan harta dalam Al-Qur'an dan Hadis. Metode tafsir yang digunakan adalah metode maudhu'I. Hasil penelitian adalah bahwa kepemilikan mutlak yaitu Allah SWT dan manusia sebagai perantara untuk menjaga dan memakmurkan bumi untuk kehidupan manusia. Dengan demikian, kepemilikan harta ini merupakan sarana untuk kehidupan manusia untuk menjaga amanah yang telah dberikan dan dipergunakan sebak-baiknya bagi kebahagiaan didunia maupun diakhirat dan juga kemaslahatan umat manusia agar dalam menjalani kehidupan yang lebih baik.
\end{abstract}

Kata kunci : Kepemilikan, Al-Qur'an dan Hadis 


\section{PENDAHULUAN}

Sebagai suatu kehidupan yang universal dan komperenshif, Islam hadir dan dipercaya oleh pemeluknya sebagai ajaran yang mengatur tentang segala bentuk aktivitas manusia, termasuk masalah ekonomi. Salah satu bentuk aktivitas yang berkaitan dengan masalah ekonomi yaitu persoalan kepemilikan (almilkiyyah). Islam senantiasa memberikan ruang dan kesempatan kepada manusia untuk mengakses segala sumber kekayaan yang dianugerahkan-nya di bumi ini, guna untuk memenuhi semua tuntutan kehidupan, memerangi kemiskinan, dan merealisasikan kesejahterakan dalam semua sisi kehidupan manusia.

Secara historis, persoalan kepemilikan sebenarnya sudah ada dan muncul sejak adanya manusia pertama di muka bumi ini. Waktu itu, makna kepemilikan tidak lebih dari sekedar penggunaan sesuatu guna memenuhi kebutuhan hidupnya, karena manusia belum berfikiran untuk menyimpan apa yang ia miliki. Dengan ini, disebabkan karena penghuni bumi saat itu masih sedikit, sedangkan kebutuhan hidup sangat melimpah. Kepemilikan terhadap sesuatu pada saat itu, hanya sekedar penggunaan untuk memenuhi kebutuhan hidupnya.(Akbar, 2012 : 124) Sebenarnya Islam mengakui bahwa eksistensi harta sangat penting untuk mendukung penyempurnaan pelaksanaan ibadah baik yang ritual ataupun sosial, bahkan jihad salah satunya harus dengan harta. Oleh karena itu, Islam melalui al-Qur'an dan Hadis memberikan tuntunan mengenai harta, agar manusia bisa memposisikan harta yang benar untuk meraih keselamatan dan kebahagiaan di dunia dan akhirat sebagaimana tujuan aktifitas ekonomi Islam. (Masrur, 2017 :96)
Islam memiliki pandangan terhadap hak milik, sebab ia dielaborasi dari AlQuran dan Hadis. Dalam pandangan Islam, pemilik mutlak seluruh alam semesta adalah Allah SWT. Sedangkan manusia adalah pemilik relative. Kepemilikan manusia terikat dengan aturan Allah SWT ia hanya bertugas melaksanakan perintah Allah atas pengelolaan alam semesta. Kesadaran bahwa kepemilikan manusia atas sumber daya ekonomi akan dipertanggung jawabkan kepada Allah di akhirat akan mendorong manusia untuk berhati-hati dalam mengelola hak milik. (Anto, 2003:94)

Tujuan artikel ini adalah fokus mengkaji mengenai bagaimana kepemilikan harta dalam Al-Qur'an dan Hadis di mana keduanya sebagai sumber ajaran yang harus dijadikan pedoman dalam mengelola kepemilikan harta. Manusia sadar akan fungsi kepemilikan harta yang sesungguhnya, dan mampu menjalaninya ke jalan yang lurus dalam mencari, menjaga, mengelola dan menggunakan sesuai dengan prinsip syariah.

\section{TINJUAN PUSTAKA \\ Metode Tafsir}

Untuk mengkaji lebih lanjut tentang ayatayat kepemilikan harta dalam Al-Qur'an serta hadis-hadis maka penulis menggunakan metode Maudhui. Metode Maudhui adalah kata maudhu'I berasal dari kata "maudhu" (موضوغ) yang merupakan isim maf'ul "wadho'a" (وضع) yang berarti meletakkan, menjadikan, mengira-ngira, mendustakan, ataupun arti maudhu'I, yang dimaksud disini adalah yang dibicarakan atau judul/topik, sehingga dapat dipahami bahwa tafsir maudhu'I adalah menjelaskan ayat-ayat Al-Qur'an berdasarkan pada judul tertentu.(Elhany, 2018:10) Sesuai dengan namanya tematik, maka yang menjadi ciri utama dari metode ini ialah menonjolkan 
tema, judul, atau topik pembahasan.(Baidan, 1998:151) Adapun tema dalam penulisan ini ialah kepemilikan harta

\section{PEMBAHASAN DAN ANALISIS \\ Konsep Kepemilikan dalam Islam}

Kepemilikan adalah suatu ikatan seseorang dengan hak miliknya yang disahkan syariah. Kepemilikan berarti pula hak khusus yang didapatkan si pemilik sehingga mempunyai hal menggunakan sejauh tidak melakukan pelanggaran pada garis-garis syariah.

Menurut hukum dasar yang namanya harta sah dimiliki kecuali hartaharta yang telah disiapkan untuk kepentingan umum, misalnya wakaf dan fasilitas umum.(Muhammad, 2004:101)

Islam memiliki pandangan yang khas mengenai masalah harta dimana semua bentuk kekayaan adalah milik Allah SWT. Demikian juga harta atau kekayaan di alam semesta ini yang telah dianugerahkan untuk semua manusia sesungguhnya merupakan pemberian dari Allah kepada manusia untuk dapat dimanfaatkan sebaikbaikknya bagi kesejahteraan seluruh umat manusia sesuai dengan kehendak Allah SWT. Semua harta baik benda maupun alat produksi adalah milik Allah sebagaimana firman Allah dalam Al-Qur'an surah AlMaidah : 120)

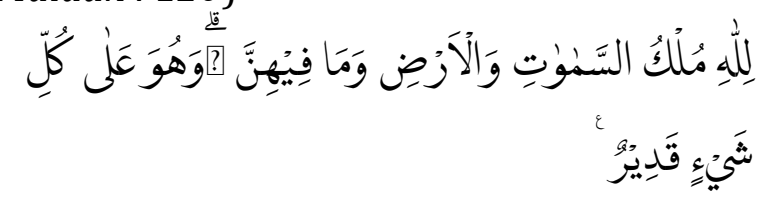

Artinya :"Milik Allah kerajaan langit dan bumi dan apa yang ada di dalamnya; dan Dia Mahakuasa atas segala sesuatu". (AlMa'idah:120)

Ayat di atas merupakan landasan dasar tentang kepemilikan dalam Islam. Ayat diatas menunjukan bahwa Allah adalah pemilik tunggal apa-apa yang ada di langit dan dibumi dan tidak ada sekutu bagi-Nya. Lantas Allah memberikan atau menitipkan kekuasaan bumi pada manusia, agar manusia mengelola dan memakmurkannya.

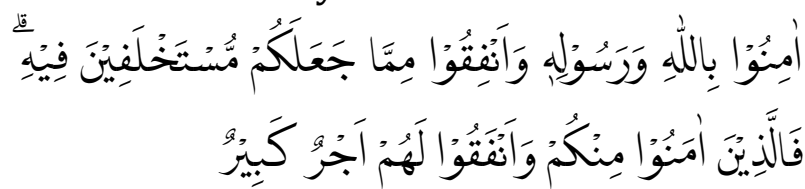

Artinya :"Berimanlah kamu kepada Allah dan Rasul-Nya dan infakkanlah (di jalan Allah) sebagian dari harta yang Dia telah menjadikan kamu sebagai penguasanya (amanah). Maka orang-orang yang beriman di antara kamu dan menginfakkan (hartanya di jalan Allah) memperoleh pahala yang besar." (QS.Al-Hadid : 7)

Menurut beberapa ayat tersebut diatas menunjukan bahwa manusia adalah wakil Allah dimuka bumi dan dianjurkan untuk mempertanggung jawabkan atas perbuatannya dan mengelola sumbersumber ekonomi sebagai suatu kepercayaan. Dengan demikian, bahwa semua harta yang ada di tangan manusia pada hakikatnya kepunyaan Allah, karena dia yang menciptakan, akan tetapi, Allah memberikan hak kepada manusia untuk memanfaatkannya (hak pakai).( Rivai \& Andi, 2009:362)

Pandangan ini bertolak belakang secara diametral dengan secara diametral dengan kapitalisme maupun sosialisme yang keduanya berakar pada pandangan yang sama yaitu materialisme. Menurut pandangan kapitalisme bahwa kekayaan yang dimiliki seseorang adalah merupakan hak milik mutlak baginya yang kemudian melahirkan pandangan kebebasan kepemilikan sebagai bagian dari pandangan hak asasi manusia (HAM). Dimana manusia bebas menentukan cara memperoleh dan memanfaatkannya. Dari pandangan inilah yang mendorong manusia barusaha 
menciptakan suatu metode atau teknologi produksi yang modern untuk dapat memperoleh keuntungan dan pendapatan yang sebesar-besarnya.

Pada sisi lain, Islam juga tidak selaras dengan pandangan sosialisme yang tidak menempatkan harkat dan martabat manusia pada proporsinya yang tidak mengakui adanya hak milik individu. Semua kekayaan milik negara dan negara akan memenuhi semua kebutuhan rakyatnya. Individu akan diberikan sebatas yang diperlukan dan dia akan bekerja sebatas kemampuannya. Alat-alat produksi dikuasai negara dan elit politik menguasai fasilitas-fasilitas publik sehingga dari sini kemudian mendorong munculnya praktik korupsi dan penyalahgunaan wewenang yang menimbulkan kerugian bagi negara dan rakyat.

Islam memiliki suatu pandangan yang khas mengenai masalah kepemilikan yang berbeda dengan pandangan kapitalisme dan sosialisme. Islam tidak mengenal adanya kebebasan kepemilikan karena pada dasarnya setiap perilaku manusia harus dalam kerangka syariah. Islam mengatur cara perolehan dan pemanfaatan kepemilikan.

Macam- macam kepemilikan yaitu (Harahap, 2015:43):

1. Kepemilikan pribadi adalah hak manusia terhadap suatu barang yang dizinkan oleh syara untuk mengalokasikan atau memanfaatkannya, dan mencegah pihak lain untuk memanfaatkannya serta memperoelh kompensasi dari barang tersebut jika milik tersebut diambil kegunaannya oleh orang lain seperti disewa, ataupun karena dikonsumsi untuk dihabiskan zatnya seperti dibeli. Afzalur Rahman mengatakan Islam mengakui adanya hak milik pribadi, dan menghargai pemiliknya. Selama harta itu diperoleh dengan cara yang benar menurut Agama Islam. Islam tidak melindungi kepemilikan harta benda yang diperoleh dengan jalan haram. Hak milik pribadi bagi manusia merupakan hak yang harus dihormati oleh siapa pun.

Dari Abu Hurairah dia berkata, " Seorang laki-laki mendatangi Rasulullah SAW seraya berkata, 'Wahai Rasulullah, bagaimana pendapatmu jika ada seorang lelaki yang ingin merampas harta bendaku? Beliau menjawab:' Jangan kamu berikan hartamu kepadanya!" Laki-laki itu bertanya lagi, lalu bagaimana jika dia hendak membunuhku? Beliau menjawab: Bunuhlah dia! Laki-laki itu bertanya lagi, Lalu bagaimana pendapatmu kalau dia berhasil membunuhku? Beliau menjawab: Maka kamu syahid. Dia bertanya lagi, 'Bagaimana pendapatmu jika aku yang berhasil membunuhnya? Beliau menjawab: Dia yang akan masuk ke dalam api neraka. (HR. Muslim)

Hadis di atas menjelaskan bahwa Islam melindungi kepemilikan pribadi dan selainnya dari pencurian dan ghasb ( pengambilan tanpa izin ), dan orang yang mati karena mempertahankan hartanya maka ia mati syahid. Sebagaimana diketahui, bahwa dasar dari pemindahan hak milik dari seseorang kepada yang lain yakni prinsip suka dan ridha. Dengan adanya prinsip suka dan sama-sama 
rela ini, maka Islam melarang memiliki barang-barang orang lain melalui jalan yang tidak sah. Karenanya orang-orang mencuri, merampas, atau mengambil barang yang bukan miliknya harus dikenakan sanksi. Adanya ketentuan ini dimaksudkkan agar harta yang dimiliki benar-benar bersih dan diridhai Allah SWT, di samping juga untuk memberikan pelajaran bagi orang-orang yang berani mengambil harta orang lain. Tujuannya adalah terciptanya kemaslahatan bersama sehingga masyarakat terhindar dari kekacauan.

2. Kepemilikan umum adalah setiap harta yang tidak masuk dalam kepemilikan individu (perorangan) dimana harta tersebut digunakan untuk kemaslahatan dan kemanfaatan umum. Dengan arti lain, barang milik bersama yaitu benda yang memiliki fungsi untuk pemenuhan kebutuhan hidup pemiliknya, namun pada saat yang sama di dalamnya terdapat hak masyarakat. Dengan kata lain, barang umum adalah benda-benda yang dapat diakses oleh semua orang secara bebas. Dalam Islam bendabenda yang termasuk dalam kategori umum yaitu benda-benda yang dimiliki komunitas secara bersamasama dan tidak boleh dikuasai oleh hanya seorang.

Dari Ibnu Abbas ia berkata, 'Rasulullah SAW bersabda: Kaum muslimin berserikat dalam tiga hal: air, rumput dan api, dan harganya adalah haram. Abu Sa'id berkata, yang dimaksud adalah air yang mengalir.' (HR. Ibnu Majah)
3. Kepemilikan negara adalah harta yang merupakan hak seluruh kaum Muslimin yang pengelolaannya menjadi wewenang negara, di mana negara dapat memberikan kepada sebagian warga negara, sesuai dengan kebijaksanaannya. Dalam pengelolaan harta-harta milik negara adalah $f a^{\prime} I$, kharaj, jizyah, dan sebagainya. Menurut Ibnu Taimiyah, sumber utama kekayaan negara adalah zakat, barang rampasan perang (ghanimah). Negara juga meningkatkan sumber penghasilan dengan mengenakan pajak warga negaranya, ketika dibutuhkan atau kebutuhannya meningkat. Demikian pula kekayaan yang tidak diketahui pemiliknya, wakaf, hibah, dan pungutan denda termasuk sumber kekayaan negara. Kekayaan negara secara actual yaitu kekayaan umum dan kepala negara hanya bertindak sebagai pemegang amanah dan negara wajib mengeluarkannya untuk kepentingan umum dan melindungi hak fakir miskin. Oleh karenanya dilarang penggunaan kekayaan negara yang berlbih-lebihan. Bahkan negara wajib mengembangkan sostem keamanan sosial dan mengurangi kesenjangan pendapatan masyarakat.

\section{Hakikat Kepemilikan}

Hakikat kepemilikan harta adalah sebagai berikut:

a) Allah adalah pencipta dan pemilik harta yang hakiki

Dalam ayat-ayat al-Qur'an, Allah swt menisbatkan kepemilikan harta itu langsung kepada Allah SWT:

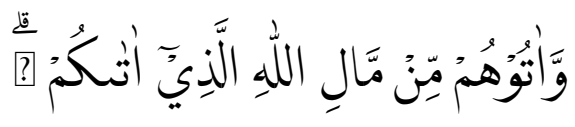


Artinya : "Dan berikanlah kepada mereka, sebagian harta yang telah dia berikan kepada kalian. (QS. An-Nur (24) :33)

Allah swt langsung menisbatkan harta kepada dirinya yang berarti harta milik Allah swt. Hal ini ditunjukan oleh

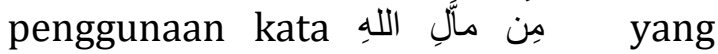
bermakna sebagian dari harta Allah swt. Allah merupakan pemilik mutlak atas seluruh harta yang ada didunia.

Kita bisa merasakan dan mencermati bahwa pemahaman seluruh harta merupakan milik Allah SWT. Siapa saja akan mengetahui bahwa tidak ada seorang pun yang akan membawa mobil, rumah, perhiasan, tanah, dan harta lainnya bila ia telah meninggal dunia. Seandainya dia yaitu manusia adalah pemilik yang hakiki, tentu saja sampai kapanpun dia akan memilikinya. Namun kenyataannya tidaklah demikian, sekalipun seseorang menghendaki membawa harta kekayaan saat ia meninggal dunia namun realitas kematian itu memustahilkan keinginannya itu. Ini merupakan bukti berupa fakta dalam kehidupan kita.

b) Harta adalah fasilitas bagi kehidupan manusia

Setelah menyatakan bahwa Allah adalah pemilik harta, Allah (dalam ayat yang sama) kemudian menganugerahkannya kepada umat manusia. Penganugerahan dari dzat maha kasih sayang ini dalam rangka memberikan fasilitas bagi kehidupan manusia. Dialah yang telah memberikan segalanya kepada manusia termasuk harta kekayaan yang ada dimuka bumi ini. Hal ini dapat dilihat dari firman Allah swt:

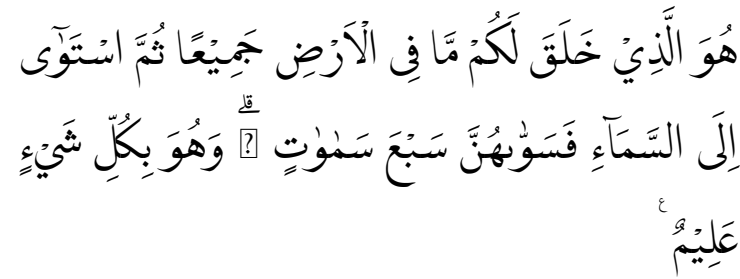

Artinya : Dialah Allah yang telah menciptakan apa saja yang ada dimuka bumi buat kalian semua. (QS. AlBaqarah (2): 29)

Ayat diatas menunjukan bahwa Allah yang memberikan hartanya kepada manusia. Selain itu, Allah juga banyak menegaskan bahwa harta kekayaan yang dimiliki manusia adalah berasal dari pemberianya. Demikian pula firmannya dalam surat:

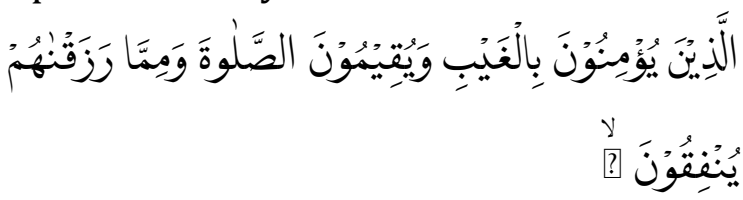

Artinya : (yaitu) mereka yang beriman kepada yang ghaib, yang menegakkan shalat, dan menafkahkan sebagian rezeki yang kami anugerahkan kepada mereka (Qs. Al-Baqarah (2): 3)

Berdasarkan ayat diatas seorang muslim hendaknya meyakini bahwa pemilik sesungguhnya harta kekayaan apapun yang ada di dunia ini hanyalah milik Allah semata. Hanya saja Allah swt telah memberikan kuasa kepada manusia untuk mengusahakan dan memanfaatkan harta tersebut.

c) Allah menganugrahkan kepemilikan harta kepada manusia

Allah swt memberi manusia sebagian dari hartanya setelah ia berupaya mencari kekayaan, Maka jadilah manusia disebut mempunyai harta. Hal ini tampak di dalam ayat alquran yang kadangkala menyebutkan harta sebagai milik manusia.misalnya: 


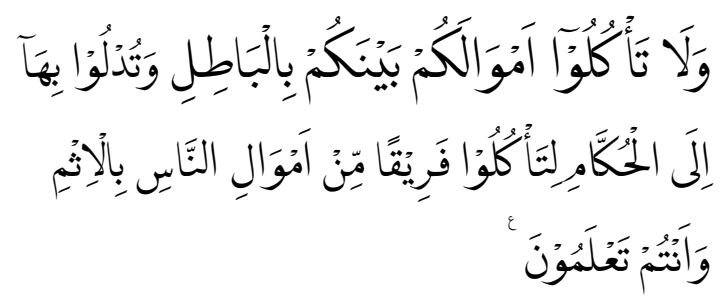

Artinya : Dan janganlah sebahagian kamu memakan harta sebahagian yang lain diantara kamu dengan jalan yang bathil. (Qs. Al-Baqarah (2):188)

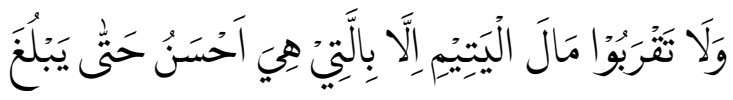

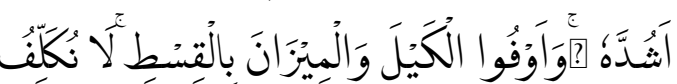

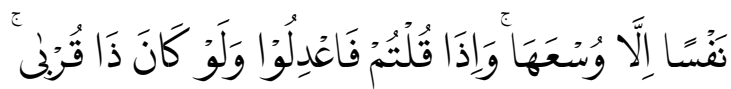

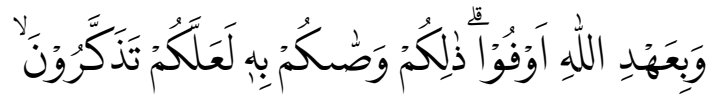

Artinya : Dan janganlah kalian dekati harta anak yatim, kecuali dengan cara yang lebih bermanfaat, hingga sampai ia dewasa. (Qs. Al-An'am (6): 152)

Ayat-ayat diatas dan ayat ayat semisal lainnya memberikan pengertian bahwa harta ketika dikaitkan dengan manusia berarti dimiliki oleh manusia sebatas hidup didunia, dan itu pun bila diperoleh dengan cara yang legal menurut syariat Islam.berdasarkan semua itu, dapat dikatakan bahwa harta hakikatnya merupakan milik Allah swt. (Sholahuddin, 2007:42)

\section{Harta dan Kepemilikan}

Dari beberapa telaah pustaka yang telah dilakukan, penulis menemukan beberapa ayat yang memiliki keterkaitan dengan tema kepemilikan. Berikut klasifikasi ayat tentang harta dan kepemilikan berdasarkan jenis Makiyyah dan Madaniyyah:

Tabel 1: Klasifikasi Makiyyah dan Madaniyyah

\begin{tabular}{|l|l|l|l|}
\hline No & $\begin{array}{l}\text { Surat Makiyyah dan } \\
\text { ayatnya }\end{array}$ & No & Surat Madaniyyah dan ayatnya \\
\hline 1 & Hud (11: 29) & 1 & Ali-Imran (3: 14) \\
\hline 2 & Al-Kahf (18: 46) & 2 & Al-Maidah (5: 120) \\
\hline 3 & Maryam (19: 77) & 3 & Al-Taubah (9: 35) \\
\hline 4 & Al-Mu'minun (23: 55) & 4 & An-Nur (24: 33) \\
\hline 5 & Ash-Shu'ara (26: 88) & 5 & Al-Ahzab (33: 27) \\
\hline 6 & An-Naml (27: 36) & & \\
\hline 7 & Al-Qalam (68: 14) & & \\
\hline 8 & Al-Humazah (104: 2) & & \\
\hline
\end{tabular}

Dalam Surah Hud (11:29) "Dan upahku kecuali atas Allah dan aku sekaliwahai kaumku, aku tiada meminta kepada kali tidak akan mengusir orang-orang yang kamu atasnya sedikit harta pun. Tidak lain telah beriman. Sesungguhnya mereka akan 
bertemu dengan Tuhan mereka, akan tetapi aku memandang kamu suatu kaum yang bodoh". Selanjutnya Nabi Nuh a.s membantah dalih kaumnya yang menyatakan bahwa beliau berbohong dan bermaksud meraih kekayaan dan kekuasaan kaumnya serta membantah pula pelecehan mereka terhadap pengikutpengikutnya. Dan Nabi Nuh a.s berkata juga membantah mereka bahwa "Wahai kaumku, bagaimana kamu menuduh aku berbohong untuk meraih harta benda dan kekuasaan kalian padahal $a k u$ sama sekali sepanjang hidupku tiada meminta kepada kamu kini dan akan datang atasnya, yakni atas seruanku kepada kamu untuk beriman sedikit harta benda pun baik sebagai hadiah, imbalan atau pemaksaan. Tidak lain upahku kecuali atas Allah, yakni imbalan atas apa yang kulakukan, tidak kuharapkan dari siapa pun kecuali dari Allah sematamata. Selanjutnya beliau meluruskan pandangan mereka tentang pengikutpengikutnya beliau dengan berkata: "Dan walaupun kalian melecehkan pengikutpengikutku karena mereka miskin dan meminta agar aku menyingkirkan tetapi aku sekali-sekali tidak akan mengusir orangorang yang telah beriman walau belum mantap iman mereka sebagaimana dipahami dari kata alladzina amanu bukan al-mu'minin. Bagaimanapun dan apa pun motivasi mereka mengikutiku, yang jelas sesungguhnya, yakni pasti mereka akan bertemu dengan Tuhan mereka pada hari kebangkitan nanti di mana semua makhluk akan kembali kepada-Nya dan ketika itu mereka akan memperoleh balasan dan ganjaran atas niat dan amal mereka. Jika demikian, aku tidak dapat menilai kalian orang-orang bijaksana akan tetapi aku memandang kamu yang menolak kerasulanku, melecehkan orang-orang lemah dan miskin serta menuduh mereka dengan aneka tuduhan palsu, adalah suatu kaum yang bodoh, yakni bersikap dan berlaku seperti orang bodoh sehingga tidak mengetahui bahwa ada hari kebangkitan dan ada juga dalam hidup ini nilai-nilai Ilahiyah yang harus dianut dan diemban, dan itulah yang menentukan kemuliaan seseorang dan membedakannya dengan yang lain, bukan kedudukan sosial atau banyaknya harta dan pengikut.(Shihab, 2006:237)

Kemudian lafaz المال pada kategori pertama, sebagaimana terdapat dalam QS. Al-Kahfi (18): 46;

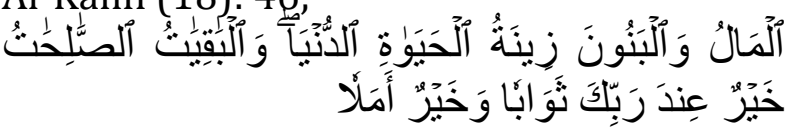

Artinya : "Harta dan anak-anak adalah perhiasan kehidupan dunia tetapi amalanamalan yang kekal lagi saleh adalah lebih baik pahalanya di sisi Tuhanmu serta lebih baik untuk menjadi harapan.". Berdasarkan penunjukan lafaz ayat ini, sangat jelas bahwa dua dari hiasan dunia yang seringkali dibanggakan manusia adalah harta dan anak. Untuk lebih jelasnya berikut ini penjelasan dari Quraish Shihab. Ayat tersebut menamai harta dan anak adalah: زينة (zinah), yaitu hiasan atau sesuatu yang dianggap baik dan indah. karena ada unsur keindahan pada harta disamping manfaat. Demikian juga pada anak, disamping anak dapat membela dan membantu orangtuanya. Penamaan keduanya sebagai zinah (hiasan), jauh lebih tepat daripada menamainya قيمة (qimah), yaitu sesuatu yang berharga. Karena kepemilikan harta dan kehadiran anak tidak dapat menjadikan seseorang berharga atau menjadi mulia. Penghargaan dan kemuliaan hanya diperoleh melalui iman dan amal saleh.(Shihab, 2006:69-71)

Selanjutnya surah Maryam (19: 77) "Lalu apakah engkau telah melihat orang yang kafir kepada ayat-ayat kami dan ia mengatakan pasti aku akan diberi harta dan anak". Ayat-ayat di atas merupakan 
lanjutan uraian tentang keburukan kepercayaan dan sikap kaum musyrikin. Kata fa / lalu pada awal ayat ini berfungsi menghubungkan ayat 77 dan seterusnya dengan ayat yang berbicara tentang ucapan dan keangkuhan kaum musyrikin dan pengingkarannya terhadap hari kebangkitan, seakan-akan ayat ini menyatakan: lalu uraikan juga kisah sang kafir yang sungguh mengherankan berikut ini. Apakah engkau telah melihat, yakni apakah engkau tidak heran melihat orang yang kafir kepada ayat-ayat kami, yakni tertipu oleh gemerlapan kehidupan dunia sehingga mengingkari hari kebangkitan dan ia mengatakan dengan nada olok-olok dan penuh keangkutan: "Aku bersumpah, di akhirat nanti pasti aku akan diberi harta yang banyak dan anak-anak yang kubanggakan. (Shihab, 2006:239)

Selanjutnya dalam QS. Al-Mu'minun (23): 55

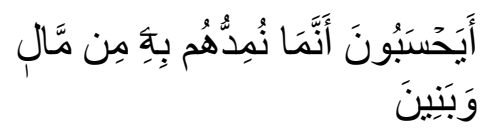

Artinya : “Apakah mereka mengira bahwa kami memberikan harta dan anakanak kepada mereka itu berarti bahwa kami segera memberikan kebaikankebaikan kepada mereka? tidak, tetapi mereka tidak menyadarinya". Ayat ini menerangkan bahwa orang-orang kafir itu telah diberdayakan oleh harta benda dan anak-anak mereka, padahal kekayaan dan anak-anak yang banyak itu bukanlah suatu tanda bahwa Allah meridhai mereka. Sebenarnya Allah memberikan kelapangan rezki kepada mereka hanya semata-mata untuk menjerumuskan mereka ke lembah kemaksiatan dan kedurhakaan, hal ini disebabkan karena sikap mereka yang sangat congkak dan sombong terhadap ajaran yang dibawa Nabi SAW.(Dahlan, 1995:530)
Kata نُمِدُهُهُ terambil dari kata امداد (imdad) atau مد (madd), keduanya bermakna memanjangkan. Yang dimaksud disini adalah menyempurnakan sesuatu atau memeliharanya sehingga berlanjut tanpa putus atau habis. Al-Qur'an biasanya menggunakan kata madd dalam arti pemberian sesuatu yang berakibat buruk, sedangkan imdad adalah yang berakibat baik. (Shihab, 2006:253)

مال Untuk lafaz المال - مالا - مال Iafaz,

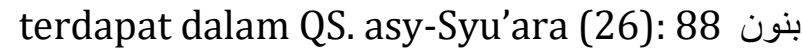
"و لا مال ينفع لا يوم pada hari ketika harta dan anak-anak tidak berguna". Ayat ini mengisyaratkan bahwa harta dan anak (keturunan) yang dimiliki waktu di dunia tak satupun yang bisa menolong. Artinya bahwa pada hari akhir nanti, manusia tidak dapat saling tolong menolong. Termasuk harta dan anak juga tidak mampu memberi perlindungan. Hanya hati yang sucilah yang dapat menyelamatkan manusia dari siksaan Allah Swt. (Dahlan, 1995:110-111)

Terkait dengan hal ini, dalam Tafsir al-Misbah dijelaskan bahwa semua sebab dan faktor yang biasa diandalkan dalam kehidupan di dunia, tidak akan berdampak positif di hari akhir. Keahlian, ilmu pengetahuan, kecantikan, kedudukan sosial dan apapun yang dimiliki manusia, semuanya tidak bermanfaat, karena manusia datang sendiri-sendiri menanggalkan segala atributnya (hal ini dapat dilihat dalam QS. al-An'am (6): 94, alMu'minun (23): 101, dan 'Abasa (80): 3436). Dan kebahagiaan pada hari itu, sematamata berdasar pada keterhindaran kalbu dari segala penyakit, walaupun yang bersangkutan tidak memiliki anak atau harta. ( Shihab, 2006:81-82)

Untuk lafaz مالV pada kategori pertama, sebagaimana terdapat dalam QS.

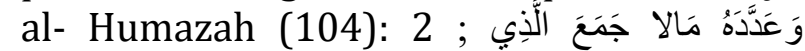
"yang mengumpulkan harta dan menghitungnya". Kata mal pada ayat ini 
berbentuk nakirah (indefinit) dan menggunakan tanwin, walaupun bunyi tersebut tidak diperjelas karena dimasukkan pengucapannya dengan huruf , yang merupakan huruf awal kata berikutnya. Tanwin atau huruf nun yang hanya diucapkan itu, oleh ulama tafsir terkadang dipahami sebagai bermakna banyak, dan bisa juga bermakna sedikit. Dengan ini kata mal pada ayat tersebut, yang berarti harta yang banyak atau sedikit.( Shihab, 2006:514)

\section{SIMPULAN}

Kesimpulan dari artikel tersebut bahwa konsep kepemilikan amanah dalam Islam adalah bahwa kepemilikan mutlak yaitu Allah SWT dan manusia sebagai perantara untuk menjaga dan memakmurkan bumi untuk kehidupan manusia. Dengan demikian, kepemilikan harta ini merupakan sarana untuk kehidupan manusia untuk menjaga amanah yang telah dberikan dan dipergunakan sebak-baiknya bagi kebahagiaan didunia maupun diakhirat dan juga kemaslahatan umat manusia agar dalam menjalani kehidupan yang lebih baik.

\section{DAFTAR RUJUKAN}

Akbar, Ali. (2012). Konsep Kepemilikan dalam Islam. Ushuluddin KVIII, No. 2.

Anto, M.B Hendri. (2003). Pengantar Ekonomi Mikro Islam. Yogyakarta: Ekonisia

Baidan, Nashruidin. (1998). Metodologi Penafsiran al-Qur'an. Yogyakarta: Pustaka Pelajar.

Dahlan, Zaini. (1995). Al-Qur'an dan Tafsirnya. Yogyakarta: Grafika.

Elhany, Hemlan. (2018). Metode Tafsir Tahlili dan Maudhu'i. Jurnal AthThariq, Vol. 2 No. 1.
Harahap,Ismail dkk. (2015). Hadis-hadis Ekonomi. Jakarta: Prenadamedia Group.

Muhammad. (2004). Ekonomi Mikro Dalam Perspektif Islam. Yogyakarta: BPFEYogyakarta.

Masrur, Muhamad. (2017). Konsep Harta dalam Al-Qur'an dan Hadits. Jurnal Hukum Islam Vol. 15, No. 1.

Rivai,Veithzal dan Buchari, (2009). Andi Islamic Economics. Jakarta: PT Bumi Aksara.

Shihab, M. Quraish. (2006). Tafsir alMisbah. Jakarta: Lentera Hati.

Sholahuddin. (2007). Asas-Asas Ekonomi Islam. Jakarta : PT Raja Grafindo Persada. 